\title{
Effect of Low-temperature Nitridation on Sulfide Stress Corrosion of 321 Austenitic Stainless Steel in $\mathrm{H}_{2} \mathrm{~S}$-Containing Environments
}

\author{
Shaoqiang $\mathrm{YU},{ }^{1)}$ Jun WANG, ${ }^{11 *}$ Hongyuan FAN, ${ }^{1)}$ Xiangfeng ZHANG, ${ }^{1)}$ Guang $\mathrm{CHEN},{ }^{1)}$ Jing $\mathrm{YAN}^{2}{ }^{2)}$ \\ Hanshan DONG ${ }^{3)}$ and Xiaoying $\mathrm{LI}^{3)}$ \\ 1) College of Manufacturing Science and Engineering, Sichuan University, Chengdu, 610065 PR China. \\ 2) Research Institute of Natural Gas Technology, PetroChina Southwest Oil and Gas Field Company, Chengdu, 610213 PR \\ China. \\ 3) School of Metallurgy and Materials, University of Birmingham, Edgbaston, Birmingham, B15 2TT UK.
}

(Received on August 18, 2018; accepted on December 17, 2018; J-STAGE Advance published date: March 14, 2019)

\begin{abstract}
The effect of low-temperature nitridation on corrosion resistance and sulfide stress corrosion (SSC) behavior of 321 austenitic stainless steel in $\mathrm{H}_{2} \mathrm{~S}$-containing environments was investigated. Varying fourpoint bend loading of 80 pct yield stress, 100 pct yield stress, 120 pct yield stress were respectively applied to nitrided 321 austenitic stainless steels. Although no macroscopic corrosion cracking is observed, pits are formed on the alloy surfaces. As the bending stress increases, the numbers and depths of pitting corrosion on the surface of the nitrided samples are getting more and more serious. Under 100 pct YS, the surface of unnitrided sample is completely destroyed and a series of jagged corrosion pits appear. The corrosion degree of the tension side is more serious than that of the compression side for a same sample. The result demonstrates that the low-temperature liquid nitridation can effectively improve the stress corrosion resistance and SSC behavior. The low-temperature nitrided sample has better stress corrosion resistance than the unnitrided sample in $\mathrm{H}_{2}$ S-containing environments and the SSC resistance of 321 austenitic stainless steel can be apparently improved by low-temperature nitridation.
\end{abstract}

KEY WORDS: austenitic stainless steel; low-temperature nitridation; S-phase; sulfide stress corrosion; corrosion resistance.

\section{Introduction}

In the process of oil and gas exploitation, the corrosion problem of oil casing is becoming more and more serious. The high temperature, high compression, $\mathrm{H}_{2} \mathrm{~S}$ and other strong corrosive environment have caused a lot of oil casting sulfide stress corrosion (SSC). In recent years, SSC has caused several serious accidents, threatening the safe operation of oil-gas fields. Stabilized austenitic stainless steels have since been widely used in modern oil-gas fields because of their integrated performance and corrosion resistance. However, their highly susceptibility to localized forms of corrosion like pitting corrosion and SSC, especially chloride-induced SSC can lead to catastrophic failure. In the same time, the material suffers from modest mechanical (low surface hardness and strength) and tribological (high friction and wear rate) properties compared to other steels that reduce its usage in many engineering fields.

It is well known that SSC is one of the most severe maintenance problems in oil-gas fields. In most cases, failures are related to hydrogen embrittlement induced by the presents of hydrogen sulfide $\left(\mathrm{H}_{2} \mathrm{~S}\right) .{ }^{1,2)}$ Hashizume and $\mathrm{al}^{3)}$ proposed a

\footnotetext{
* Corresponding author: E-mail: srwangjun@scu.edu.cn DOI: https://doi.org/10.2355/isijinternational.ISIJINT-2018-515
}

correlation between metal chemical composition and depassivation $\mathrm{pH}$ in sour media. The interpretation should be that of $\mathrm{H}_{2} \mathrm{~S}$ reacting with metal surface to produce metallic sulfides, hence releasing hydrogen that can be absorbed and yield a strong local decrease in mechanical properties. ${ }^{4,5}$ Lauvstad et al. showed the effects of $\mathrm{H}_{2} \mathrm{~S}$ and $\mathrm{Cl}^{-}$on the pitting initiation and found that oxidation of sulfide constitutes an extra anodic reaction in the passive potential range, significantly increasing the transportation of electrons through the oxide. ${ }^{6}$

The liquid nitriding is a highly effective and low-cost method with many advantages such as low nitriding temperature, short treatment time, high degrees of shape and dimension stabilities, and easy reproducibility. ${ }^{7,8)}$ It has been established that an S-phase, also known as "expanded austenite" layer which can be formed on 321 austenitic stainless steel by low-temperature nitridation can enhance the mechanical properties of austenitic stainless steels, such as hardness, wear resistance and fatigue properties, ${ }^{9}{ }^{9}$ and even better corrosion resistance including intergranular corrosion resistance property in some cases. ${ }^{10,11)}$ The low-temperature surface nitridation can generate very large compressive residual stress in the nitrided layer of austenitic stainless steel. Yawei Peng proposed that the improvement of the SSC resistance was attributed to the compressive 
residual stress and the improved pitting corrosion resistance after low-temperature surface carburization. ${ }^{12)}$ Alternatively, Dong found that the high nitrogen content of the S-phase can improve the pitting corrosion resistance. ${ }^{13)} \mathrm{W}$. Li examined that samples with S-phase layers have higher resistance to hydrogen embrittlement comparing with untreated counterparts and hydrogen induced phase transition was suppressed by S-phase formed, which is beneficial to improving the resistance to hydrogen embrittlement. ${ }^{14)}$

The aim of the present paper is to highlight the role of the low-temperature liquid nitridation on the SSC mechanism of 321 austenitic stainless steel in sour media. Unnitrided and nitrided 321 stainless steel were exposed in the test solution with varying four-point bend loading. It is demonstrated that the low-temperature liquid nitridation can improve the corrosion resistance of stainless steel and prolong its service life in the sour corrosion environment.

\section{Experimental Procedure}

\subsection{Materials and Low-temperature Liquid Nitriding}

The samples were prepared from a 321 stainless steel coupon with the composition (wt.\%): C 0.08, Si 1.00, Mn 2.00, P 0.045, S 0.030, Ni 9.00-12.00, Cr 17.00-19.00 and Ti $0.40-0.70$. The samples were cut into a size of $78 \mathrm{~mm} \times$ $8 \mathrm{~mm} \times 1.5 \mathrm{~mm}$ and numbered in $1,2,3$ and 4 .

Liquid nitriding technology is a environment-friendly low-temperature liquid nitriding treatment technology which is mainly composed of cyanate. The sample 1, 2, 3 were nitrided in the non-toxic cyanate salt bath at $703 \mathrm{~K}\left(430^{\circ} \mathrm{C}\right)$ for 8 hours. The nascent nitrogen utilized for nitriding reaction comes from the dissociation of $\mathrm{CNO}^{-}: 4 \mathrm{CNO}^{-} \rightarrow \mathrm{CO}^{2-}+$ $2 \mathrm{CN}^{-}+\mathrm{CO}^{-}+2[\mathrm{~N}] .{ }^{15)}$ The concentration difference between the surface of the sample and the nitride bath drives the active nitrogen atoms to permeate the austenite structure, leading to the formation of the nitrogen-supersaturated S-phase. In the meantime, a few nascent carbons also permeate in the austenite structure. Samples were subjected to both nitriding and SSC testing except for sample 4 which was only subjected to SSC testing but not nitriding and was called unnitrided sample.

\subsection{Sulfide Stress Corrosion Tests}

According to NACE TM0177-2005, the four-point bending (FPB) test was used to assess the effect of the low-temperature liquid nitridation of 321 austenitic stainless steel on SSC susceptibility in a simulated sour environment. The FPB test device was placed in $\mathrm{H}_{2} \mathrm{~S}$-containing environments for 30 days. Nitrided samples 1, 2, 3 were respectively loaded to $80 \%(164 \mathrm{MPa}), 100 \%(205 \mathrm{MPa})$ and $120 \%(246 \mathrm{MPa})$ of the alloy yield strength $(205 \mathrm{MPa})$.

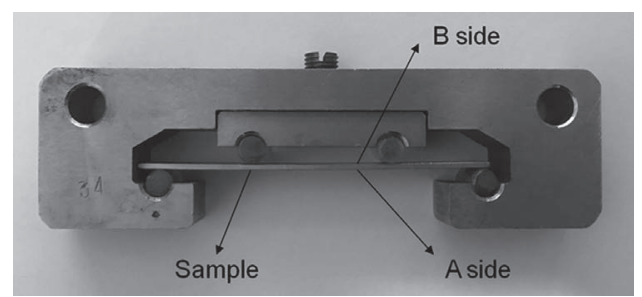

Fig. 1. FPB apparatus.
And the unnitrided one (sample 4) was load to $100 \%$ of the alloy yield strength. After the SSC tests, the samples were then thoroughly washed with alcohol and dried. The FPB apparatus was shown in Fig. 1. In order to maintain the same condition as the actual pipeline working conditions, the middle part of the sample which was only subjected to bending stress without any shear stress is selected for analysis. The lower side and upper side of the middle part which were respectively subjected to pure tension and pure compression are expressed in A side and B side, respectively.

\subsection{Physical Characterizations}

The transverse sections of samples were metallographically polished and chemically etched in etchant containing hydrochloric acid, nitric acid, and water, with the ratio of 2:1:1. An OLYMPUS GX51 optical microscope was used for metallographic analysis. The near-surface and cross-sectional microstructures were characterized using JSM-6510 scanning electronic microscopy (SEM) and the phase constituents were determined by An EMPYREAN $\mathrm{X}$-ray diffractometer (XRD) using $\mathrm{Cu}-\mathrm{K} \alpha$ radiation. X-ray photoelectron spectroscopy (XPS) was used to analyze the surface corrosion products. Post SSC tests, the samples were cross-sectional, analyzed by an SHIMADZU-1720 electron probe microanalysis (EPMA). Corrosion products on the surfaces of the tests samples have then been characterized using energy dispersive X-ray spectroscopy (EDX). Hardness measurements were made by a HVS-1000 Vickers hardness machine, with a test load of $10 \mathrm{~g}$ and holding

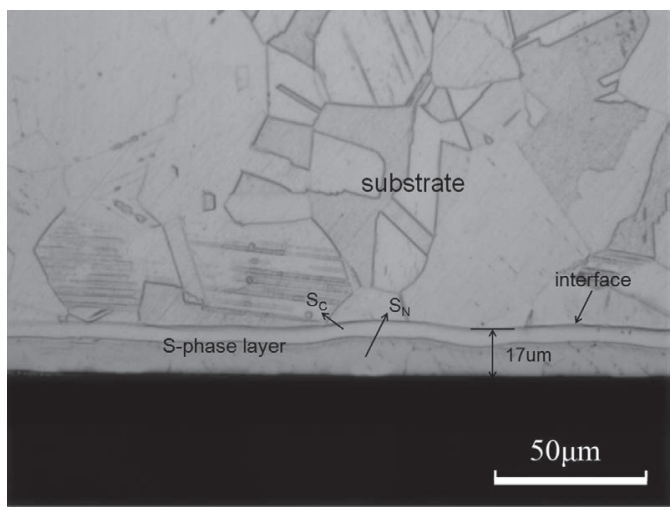

Fig. 2. Optical micrograph of the S-phase layer on nitrided 321 stainless steel at $703 \mathrm{~K}\left(430^{\circ} \mathrm{C}\right)$ for $8 \mathrm{~h}$.

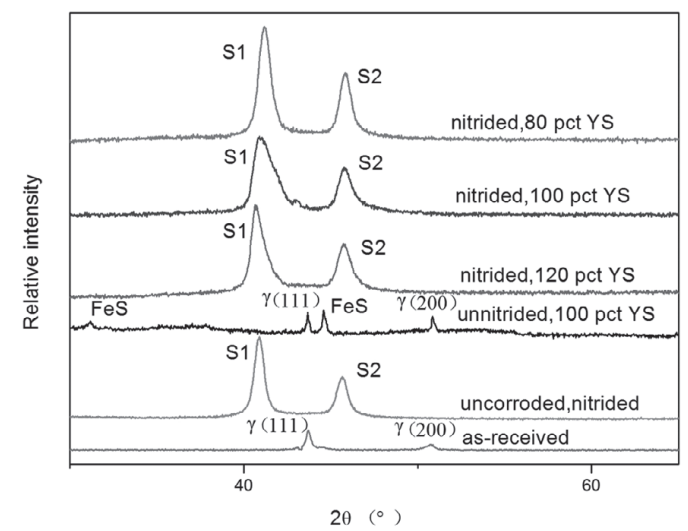

Fig. 3. XRD patterns acquired from nitrided and unnitrided specimens in various conditions. 
duration of $15 \mathrm{~s}$.

\section{Results and Discussion}

\subsection{Metallography and X-ray Diffraction Analysis}

Figure 2 shows the cross-sectional microstructures of the nitrided 321 stainless steel. A completely uniform bright white layer was formed on the surface of the samples, which was called the S-phase layer. The S-phase layer has a double-layer structure: a nitrogen $\mathrm{S}$-phase outer layer $\left(\mathrm{S}_{\mathrm{N}}\right)$; and a carbon S-phase inner layer $\left(\mathrm{S}_{\mathrm{C}}\right)$. The thickness of the $\mathrm{S}$-phase layer is approximately $17 \mu \mathrm{m}$. In the optical micro-
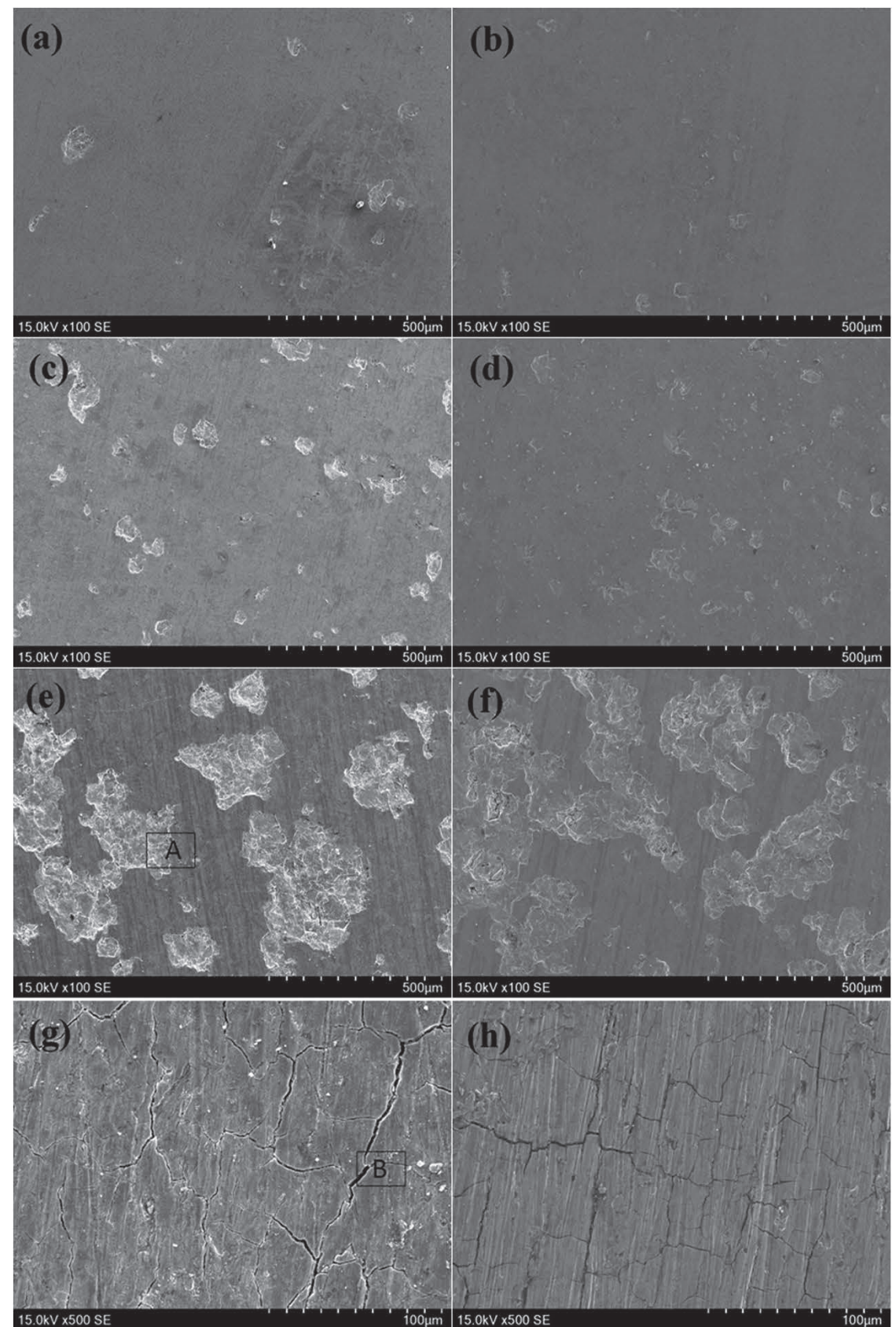

(i)

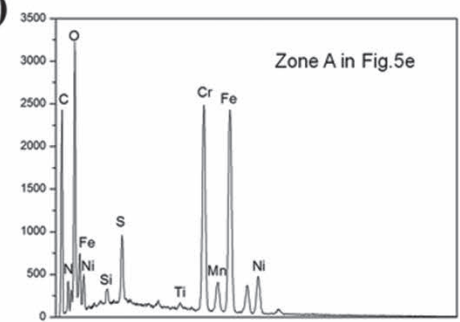

(j)

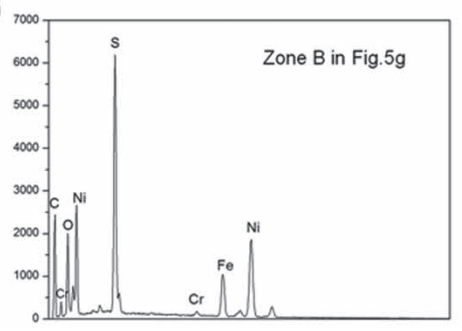

Fig. 4. SEM images and EDS of nitrided and unnitrided samples after stress corrosion for 30 days. (a) nitrided, 164 $\mathrm{MPa}$, A side (b) nitrided, $164 \mathrm{MPa}, \mathrm{B}$ side (c) nitrided, $205 \mathrm{MPa}$, A side (d) nitrided, $205 \mathrm{MPa}, \mathrm{B}$ side (e) nitrided, $246 \mathrm{MPa}$, A side (f) nitrided, $246 \mathrm{MPa}$, B side (g) unnitrided, $205 \mathrm{MPa}$, A side (h) unnitrided, 205 MPa, B side (i) EDS of test after corrosion for nitrided (j) EDS of test after corrosion for unnitrided. 
graphs (Fig. 2), the interface between the S-phase layer and the matrix appears as a dark line due to the height difference between these regions, caused by their unequal response to the etchant. ${ }^{16)}$

The X-ray diffraction (XRD) pattern of unnitrided and nitrided 321 samples under varying loading stresses in $\mathrm{H}_{2} \mathrm{~S}$-containing environments is presented in Fig. 3. All nitrided samples exhibited diffraction peaks attributable to the S-phase, which is believed to be a supersaturated solid solution of nitrogen in austenite FCC structure. ${ }^{17)}$ It is seen that the formation of the S-phase layer is well identified by its two peaks, S1 (111) and S2 (200), in all nitrided layers. These two diffraction peaks in the pattern of the nitrided samples shifted to the lower angles compared to that in the pattern of the untreated sample which was due to the lattice expansion introduced by nitrogen. The lattice parameter $(\mathrm{a}=0.385 \mathrm{~nm})$ of the nitrided layer increased compared to the substrate $(\mathrm{a}=0.360 \mathrm{~nm})$. The shift and broadening of the peaks are associated with the 'expanded austenite' produced by nitrogen supersaturations. ${ }^{16,18)}$ The diffraction peaks related to oxygen and sulphur elements of the nitrided sample are not found, which demonstrates that the corrosion

(a)

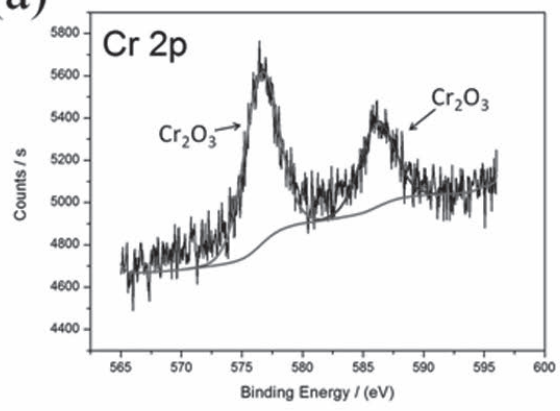

(c)

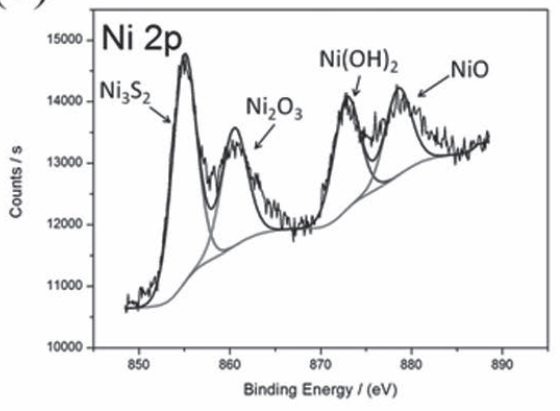

products and the oxide layer on the nitrided layer surface are not detected which may be due to its low content. As is shown in Fig. 3, there is a weak peak due to FeS on the unnitrided sample.

\subsection{Surface Morphology after SSC Tests}

Figure 4 shows the surface morphology of nitrided and unnitrided samples after 30 days of corrosion in $\mathrm{H}_{2} \mathrm{~S}$-containing environments. The numbers and the depths of pits of the nitrided samples are more serious with the increase of applied stress (Figs. 4(a) to 4(f)). The pitting density also validated the above results. Under 100 pet YS, the unnitrided sample is the most severely damaged sample after SSC test. Numerous cracks can be observed on the unnitrided sample as shown in Figs. 4(g) and 4(h). The corrosion could preferentially occur at grain boundaries, resulting in the formation of cracks under stress in a corrosive environment. In a sour environment, $\mathrm{HS}^{-}$and $\mathrm{S}^{2-}$ decomposed by $\mathrm{H}_{2} \mathrm{~S}$ are adsorbed on the metal surface and subsequently form a electrochemical cell which involves the anodic dissolution of iron accompanied by the half-cell reaction at the cathode side which can be expressed by a (b)

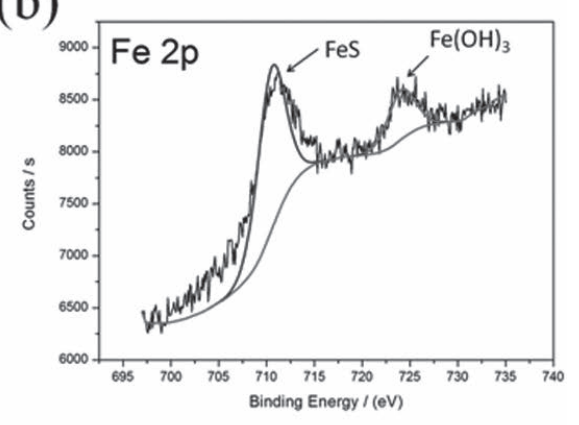

(d)

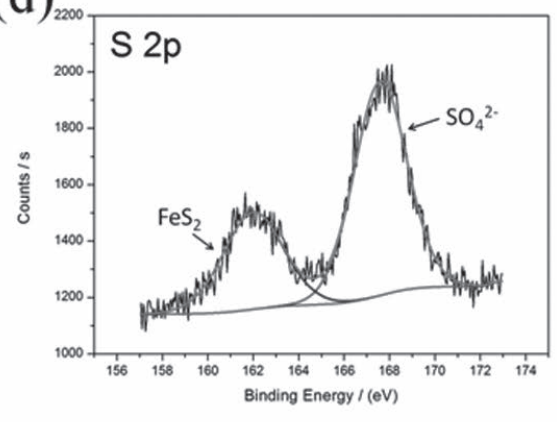

(e)

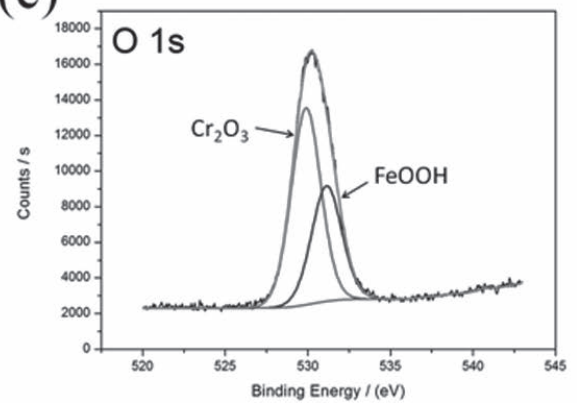

Fig. 5. XPS spectra of $\mathrm{Cr} 2 \mathrm{p}, \mathrm{Fe} 2 \mathrm{p}$, Ni 2p, S 2p, O 1s energy region for the corrosion products layer of the unnitrided sample after 30 days aging in $\mathrm{H}_{2} \mathrm{~S}$-containing environments. 
chemical equation as follows.

$$
2 \mathrm{H}^{+}+2 \mathrm{e}^{-} \rightarrow \mathrm{H}_{2}
$$

Berkowitz BJ suggested that the hydrogen adsorbed at the surface can either recombine to form $\mathrm{H}_{2}$ or be absorbed into the metal on the atomic form. Hydrogen atoms segregated and diffused preferentially along the grain boundaries causing intergranular embrittlement and subsequent crack propagation when sufficient tensile stress was applied. ${ }^{19)}$

Due to the low content of FeS and its poor adherence to the substrate, it is thought that the corrosion product FeS possibly forms on the unnitrided surface. Based on the Figs. 4(i) and 4(j), the major elements such as Fe, Cr, S, C, O and $\mathrm{Ni}$ can be detected on the surface of the nitrided and unnitrided samples, which suggests that the corrosion products are probably complex compounds containing different types of iron sulfides and iron carbonates. On the other hand, $\mathrm{Fe}$ and $\mathrm{Cr}$ peaks with respect to sulfur peak acquired from the nitrided sample are obviously lower than that of the unnitrided one which can be speculated that the surface of unnitrided sample can not play a good role in protecting the matrix, which suggests that such loose corrosion products could probably exacerbate pitting corrosion.

The 321 austenitic stainless steel tends to form a chromium-rich passive film on the surface. In $\mathrm{H} 2 \mathrm{~S}$-containing environments, if stable films of iron sulphide are formed when the material is immersed, ${ }^{20)}$ they can provide further protection by acting as an additional barrier for the diffusion of ferrous ions and therefore reduce the corrosion rate. However, this passive film can be locally damaged in the presence of tensile stress. $\mathrm{HS}^{-}$and $\mathrm{S}^{2-}$ continue to adsorb onto the freshly exposed metal surface and subsequently form a cell system, which accelerates acidification in corrosion pits. ${ }^{21)}$ Besides, $\mathrm{H}_{2} \mathrm{~S}$ can increase the iron dissolution rate by forming iron sulphide as opposed to ferrous ion. ${ }^{19)} \mathrm{With}^{2-}$, $\mathrm{HS}^{-}$, and $\mathrm{H}^{+}$constantly penetrate through the passive film, there will be a repeated cycle where the metal matrix forms a passive film, the passive film ruptures, and the matrix dissolves. ${ }^{22)}$ As a result, the corrosion pit eventually form.

For a same tested sample, different sides have suffered different degrees of pitting corrosion damage. The corrosion degree of A side is more serious than that of $\mathrm{B}$ side (as shown in Figs. 4(a) to 4(h)), which is also described in Figs. 8(a) to 8(h). Simultaneously, the surface of the nitrided (a)

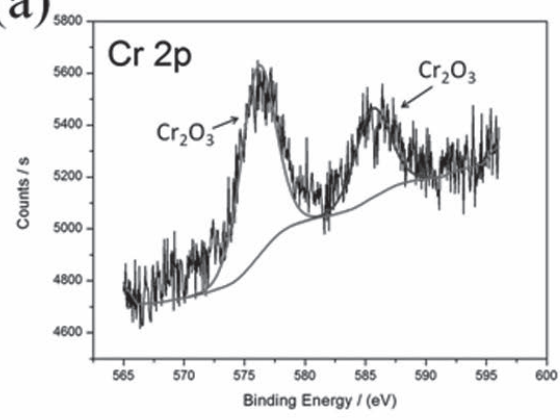

(c)

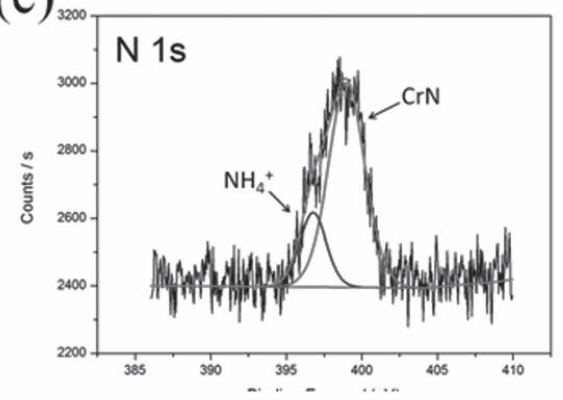

(e)

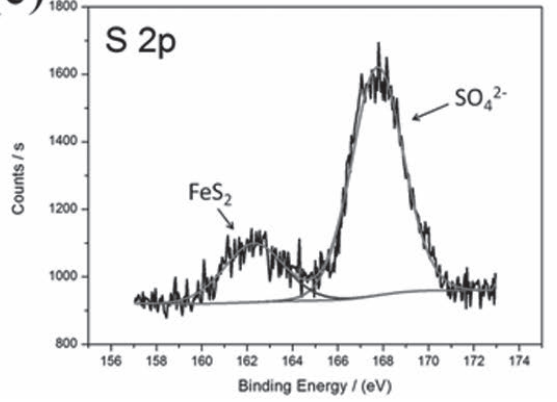

(b)

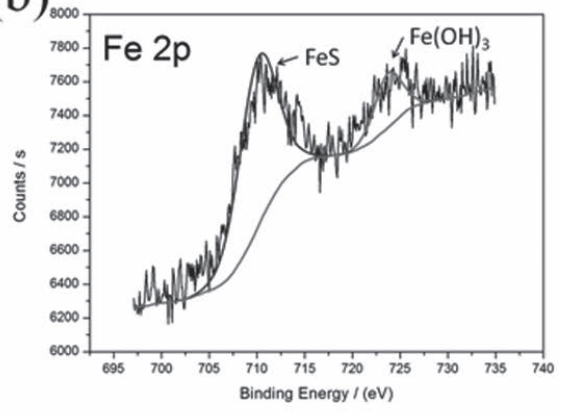

(d)

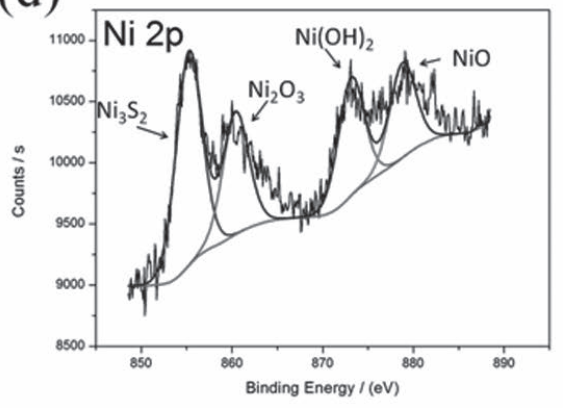

(f)

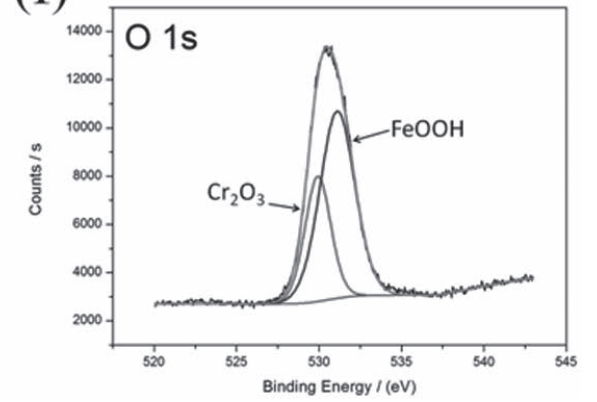

Fig. 6. XPS spectra of Cr 2p, Fe 2p, N 1S, Ni 2p, S 2p, O 1s energy region for the corrosion products layer of the nitrided sample under $246 \mathrm{MPa}$ after 30 days aging in $\mathrm{H}_{2} \mathrm{~S}$-containing environments. 
samples are accompanied by the exfoliation of the nitrided layer and the degree of falling off is getting more and more serious with the increase of the applied stress. It is clear that the damage degree and the degree of falling off of A side is greater than that of B side for a same nitrided sample which may be because that the tensile stress applied on A side relieved the residual compressive stress, which increased the sensitivity of the stress corrosion. However, the compressive stress applied on B side further increased the stability of the nitrided layer of the $\mathrm{B}$ side, which would be conducive to enhance the ability of the B side to resist stress corrosion. On the other hand, extremely high hardness of the S-phase layer inevitably resulted in a decrease in its toughness and an increase in its brittleness, which makes the nitrided layer easy to fall off when the stress is applied.

Figures 5 and 6 shows the XPS spectra of Cr 2p, Fe 2p, $\mathrm{Ni} 2 \mathrm{p}, \mathrm{N} 1 \mathrm{~s}, \mathrm{O} 1 \mathrm{~s}, \mathrm{~S} 2 \mathrm{p}$ energy region for the corrosion products layer after 30 days aging in $\mathrm{H}_{2} \mathrm{~S}$-containing environments, which was to clarify the chemical compositions of the corrosion products of the unnitrided and nitrided samples. In the corrosion products, $\mathrm{Fe} 2 \mathrm{p}$ has two main peaks. The electron binding energy is $711 \mathrm{eV}$ and $725 \mathrm{eV}$
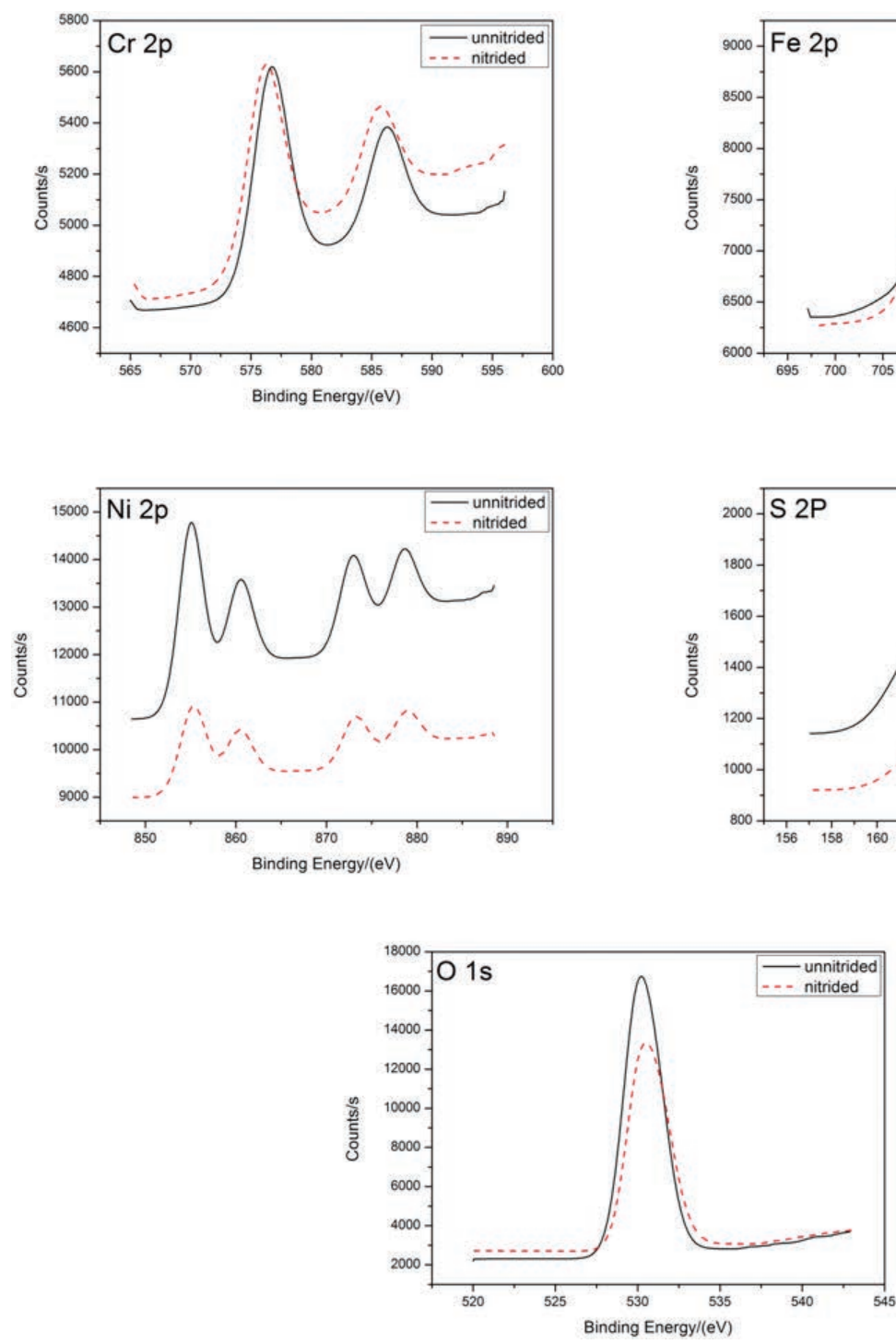

Fig. 7. XPS spectra of nitrided and unnitrided samples after 30 days aging in $\mathrm{H}_{2} \mathrm{~S}$-containing environments focused on $\mathrm{Cr} 2 \mathrm{p}, \mathrm{Fe} 2 \mathrm{p}, \mathrm{Ni} 2 \mathrm{p}, \mathrm{S} 2 \mathrm{p}, \mathrm{O}$ 1s. (Online version in color.)
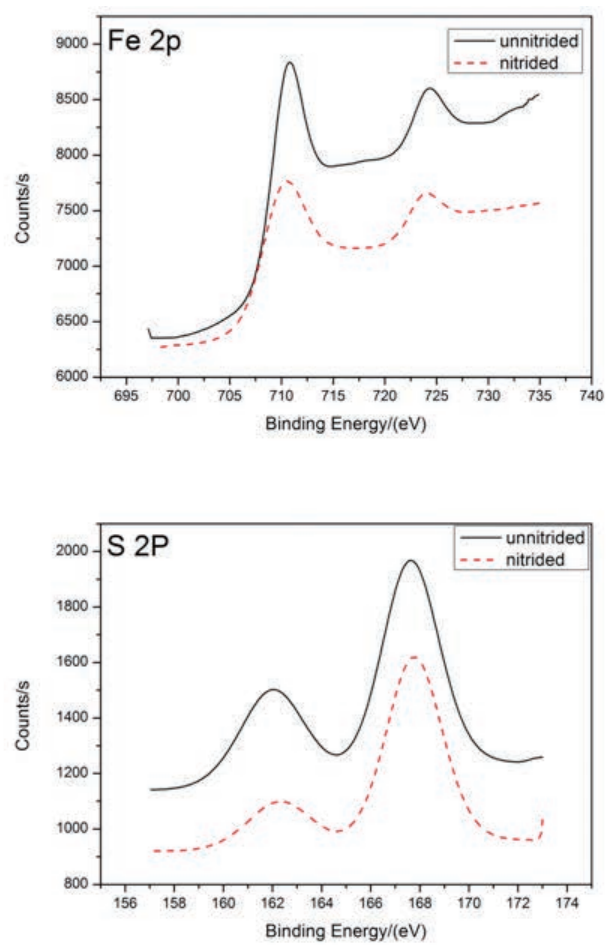

respectively, indicating that the corrosion products of $\mathrm{Fe}$ element are mainly $\mathrm{FeS}$ and $\mathrm{Fe}(\mathrm{OH})_{3}$. The electron binding energy of $\mathrm{O} 1 \mathrm{~s}$ is about $529.9 \mathrm{eV}$ and $531.1 \mathrm{eV}$, indicating the corresponding corrosion products are $\mathrm{Cr}_{2} \mathrm{O}_{3}$ and $\mathrm{FeOOH}$ respectively. The characteristic peaks of $\mathrm{Cr}$ in corrosion products are mainly $\mathrm{Cr}_{2} \mathrm{O}_{3}$. The existence of $\mathrm{Ni}$ element in corrosion products is more complicated, which includes some small energy peaks. Many researchers try to analyze the products formed by nickel and sulfur in $\mathrm{H}_{2} \mathrm{~S}$-containing environments, but it is difficult to determine the electron binding energy. The energy peaks of $\mathrm{Ni}$ are mainly 855.8 $\mathrm{eV}, 861.6 \mathrm{eV}, 873.5 \mathrm{eV}$ and 879.4, and the corresponding substances are $\mathrm{Ni}_{3} \mathrm{~S}_{2}, \mathrm{Ni}_{2} \mathrm{O}_{3}, \mathrm{Ni}(\mathrm{OH})_{2}$ and $\mathrm{NiO}$. ${ }^{23)}$ The corrosion products not only contain sulfides of nickel but also oxides and hydroxides of nickel. The sulfides of nickel has no protective effect on the material. According to the corrosive environment, $\mathrm{S} 2 \mathrm{p}$ will form the sulfide corrosion product in the corrosion. Sulfur is particularly sensitive to oxygen in corrosion products, which will affect the corrosion behavior of the material. When exposed to air in the later stage, sulfur oxides will form on the surface. In the corrosion products, S $2 p$ has two main peaks, and the elec- 
tron binding energy is $162.2 \mathrm{eV}$ and $168.6 \mathrm{eV}$ respectively. The corresponding corrosion products are the $\mathrm{FeS}_{2}$ formed by the reaction of $\mathrm{Fe}$ and $\mathrm{H}_{2} \mathrm{~S}$, and the $\mathrm{MSO}_{4}$ formed by the immersion of oxygen. ${ }^{24)}$ For low-temperature nitrided samples, there is a large amount of active nitrogen atoms on the surface of the sample due to the formation of nitrogen supersaturated extended austenite layer. These $\mathrm{N}$ atoms can combine with the $\mathrm{H}^{+}$in the corrosive environment to form $\mathrm{NH}_{4}{ }^{+}$, prevent the $\mathrm{pH}$ value of the solution from decreasing and slow down the further corrosion of the material. By analyzing the N $1 \mathrm{~s}$ valence state, there are two peaks of 396.7 $\mathrm{eV}$ and $397.6 \mathrm{eV}$. According to the electron binding energy, it is the $\mathrm{CrN}$ formed with $\mathrm{Cr}$ and the $\mathrm{NH}_{4}{ }^{+}$formed with $\mathrm{H}^{+}$respectively, ${ }^{25,26)}$ which is consistent with the corrosion products of other low-temperature surface nitrided materials after the corrosion in $\mathrm{H}_{2} \mathrm{~S}$-containing environments. The extended austenite formed on the surface of the material after the low-temperature surface treatment can change the local corrosion environment on the surface of the material, protect the metal matrix and reduce the corrosion rate.

It can be clearly seen from Fig. 7 that the content of sulfur elements on the surface of the unnitrided sample is obviously higher than that of the nitrided sample, which means that low-temperature nitridation can reduce the formation of the corrosion products in $\mathrm{H}_{2} \mathrm{~S}$-containing environments, further corrosion of the sample is prevented.

As is shown in Fig. 4, low-temperature nitrided samples have better corrosion resistance than unnitrided sample and the matrix is almost not affected, which can be explained by the supersaturated nitrogen atoms in the S-phase. It is well known that just a little amount of interstitial nitrogen in austenitic stainless steels allows to increase sensibly their pitting corrosion resistance through several proposed mechanisms. ${ }^{27,28)}$ S-phase is supersaturated with active nitrogen atoms, which combine with $\mathrm{H}^{+}$to avoid surface $\mathrm{pH}$ reduction, and thus decelerate $\mathrm{H}_{2} \mathrm{~S}$ corrosion. ${ }^{29)}$ At the same time, active nitrogen atoms can accelerate the formation of the passive film and influence repassivation kinetics, thus inhibiting stable pitting growth and improving the density of the passive film. ${ }^{30)}$

For the nitrided four-point bend loaded samples, the measured surface stresses were highly compressive attributed to the huge compressive residual stress at the surface of the nitrided samples which were introduced during low-temperature surface nitridation. The supersaturated interstitials cause large lattice expansion while the unnitrided bulk material constrains this expansion, causing the S-phase layer to have very high residual stresses. ${ }^{31)}$ High residual stresses and greater lattice expansions can reduce fracture resistance, facilitating the initiation of cracks on the nitrided surface layer. ${ }^{32,33)}$ Therefore, when the exerted stress is increasing, the damage of the surface of the nitrided pattern will be aggravated. Once the externally applied stresses over overcome the compressive residual stresses, it is prone to crack. $^{29)}$

\subsection{Cross-section Investigation and Microhardness after SCC Tests}

The cross-sectional morphology of nitrided and unnitrided samples under varying loading stresses after 30 days of corrosion in $\mathrm{a}_{2} \mathrm{~S}$-containing environments is shown in
Fig. 8. No macroscopic cracking is found on all nitrided samples but pitting. However, microcracks can be observed in the S-phase layer of the nitrided samples, which is due to the joint action of applied stress and a sour environment. The unnitrided sample is the most severely damaged sample after SSC test (Figs. 8(g) and 8(h)). With increasing stress, pitting and corrosion of the nitrided samples are aggravated (Figs. 8(a) to 8(f)).

To analyze the change rule of element content from the surface to the matrix in the sample, EPMA has been performed for the nitrided and unnitrided samples under different stresses as reported in Fig. 9. The depth in the figures reflects the distance from the surface of the material to the inside of the matrix. The content of the elements $\mathrm{Cr}$, $\mathrm{Fe}$ and $\mathrm{Ni}$ which are critical to the formation of a passive film fall sharply on the surface, jeopardizing the corrosion resistance, especially the unnitrided sample, and lead to the appearance of a large number of corrosion pits on the surface finally. The $\mathrm{N}$ content of nitrided samples is highest at the surface and drops as the case hardness decreases due to the formation of supersaturated austenite which can improve the corrosion resistance. And the diffusion depth of $\mathrm{N}$ ele-

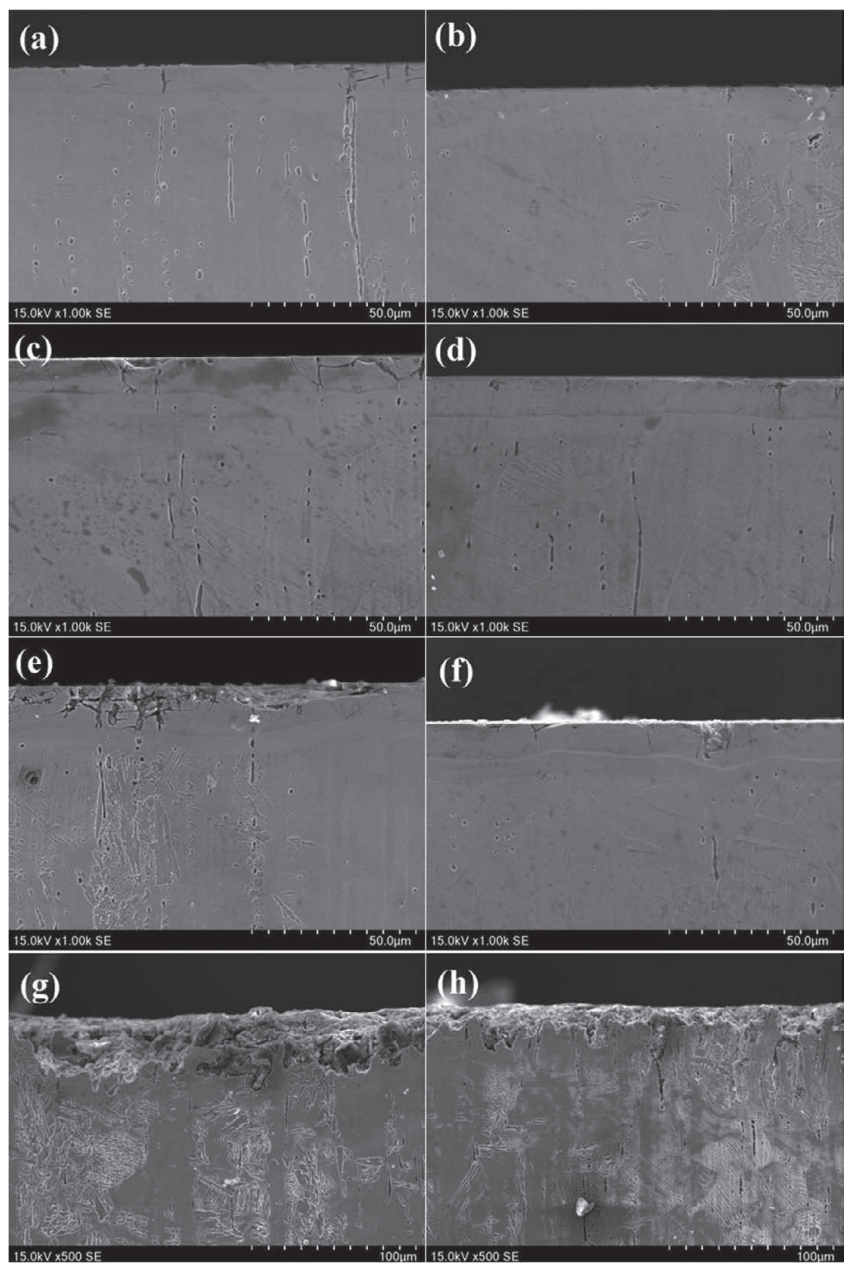

Fig. 8. Cross-sectional SEM images of samples with different stresses in $\mathrm{H}_{2} \mathrm{~S}$-containing environments for 30 days (a) nitrided, $164 \mathrm{MPa}$, A side (b) nitrided, $164 \mathrm{MPa}$, B side (c) nitrided, $205 \mathrm{MPa}$, A side (d) nitrided, $205 \mathrm{MPa}$, B side (e) nitrided, $246 \mathrm{MPa}$, A side (f) nitrided, $246 \mathrm{MPa}$, B side (g) unnitrided, $205 \mathrm{MPa}$, A side (h) unnitrided, $205 \mathrm{MPa}$, B side. 
(a)

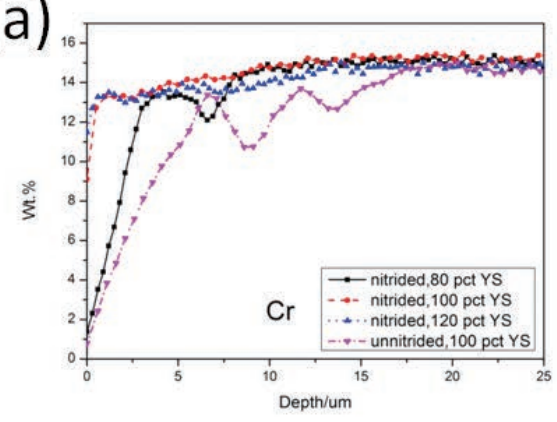

(c)

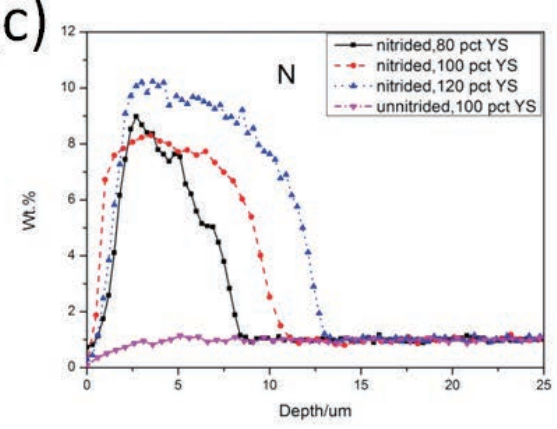

(e)

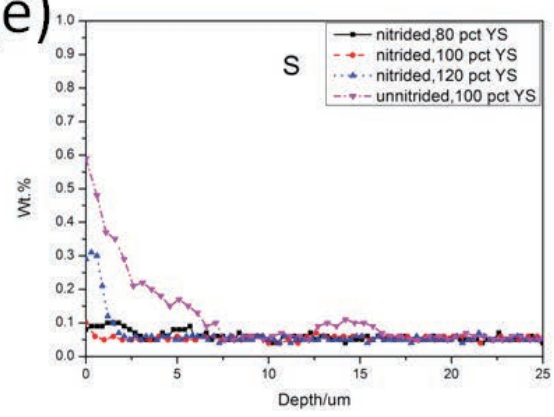

(b)

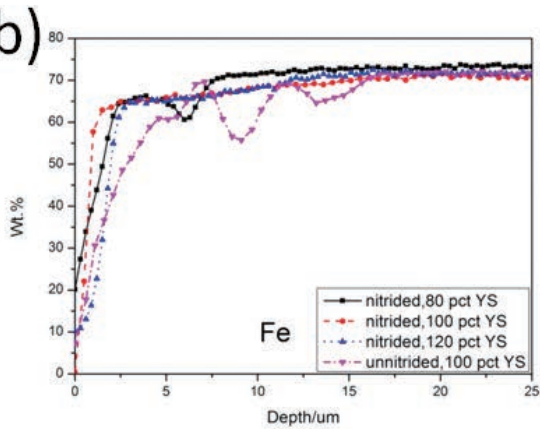

(d)

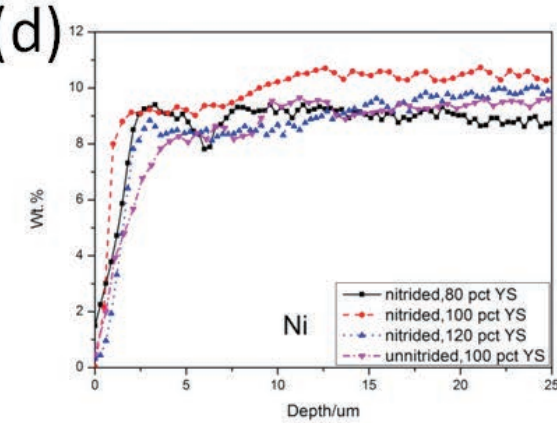

(f)

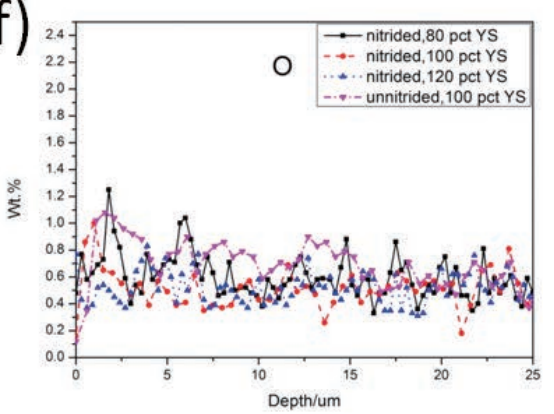

Fig. 9. EPMA images of nitrided and unnitrided samples under various stresses. (a) Cr element profile, (b) Fe element profile, (c) N element profile, (d) Ni element profile, (e) S element profile, and (f) O element profile. (Online version in color.)

ment increases with the increase of loading stress. A. H. Heuer proposed that the driving force for nitrogen diffusion is not only the concentration gradient, but also the gradient of the compositionally induced internal stress. ${ }^{34)}$ Apart from the increase of sulfur element content on the surface of unnitrided sample, the content of sulfur and oxygen on the other samples has little change. But due to the EPMA analysis is based on line scanning, the analysis results have certain contingency.

It is well known that a sour environment containing $\mathrm{H}_{2} \mathrm{~S}$ enhances the hydrogen absorption into the metal. Hydrogen tends to segregate upon straining with concentrated stress, reducing the boundary cohesive strength, promoting the initiation of microcracks from the phase transitional boundaries causing hydrogen embrittlement. ${ }^{35)}$ According to Fig. 8 , the surface of the unnitrided sample is almost completely destroyed (Figs. 8(g) and 8(h)), while the nitrided samples have no change except that pitting corrosion and microcracks occur on the S-phase layer (as shown in Figs. 8(a) to 8(f)). The results demonstrated that low-temperature nitridation can effectively resist hydrogen absorption and improving the corrosion resistance. The nitrogen atoms introduced by low-temperature liquid nitridation can immerge into the austenite matrix to form supersaturated solid solution, resulting in lattice distortion. Consequently, interstitial sites are blocked and hydrogen can be trapped in the nitride precipitates, and the absorption of hydrogen by the steel substrate is diminished, which means nitriding can effectively decrease the hydrogen permeation rate in the $\mathrm{H}_{2} \mathrm{~S}$ atmosphere. ${ }^{36,37)}$ In the other hand, a large amount of interstitial nitrogen in the S-phase layer increases the stability of austenite, inhibits the hydrogen-induced phase transition of the surface, and the growth of surface microcracks is effectively restrained. ${ }^{14)}$ As a result, the ductility and resistance to hydrogen embrittlement of the stainless steel are enhanced and the low-temperature surface nitridation can significantly improve the hydrogen embrittlement resistance.

The EDX microanalysis of $\mathrm{Cr}, \mathrm{Fe}, \mathrm{Ni}, \mathrm{O}, \mathrm{N}$ and $\mathrm{S}$ of the unnitrided sample under $164 \mathrm{MPa}$ and nitrided sample under $246 \mathrm{MPa}$ is given in Fig. 10. As expected, $\mathrm{Fe}, \mathrm{Ni}$ and $\mathrm{Cr}$ signals are concentrated in the matrix, and they seem to be completely absent in the corrosion products layer, which is also shown in Fig. 7. Sulfur and oxygen seem to be the main elements of the corrosion products layer. Nevertheless, due 
(a)

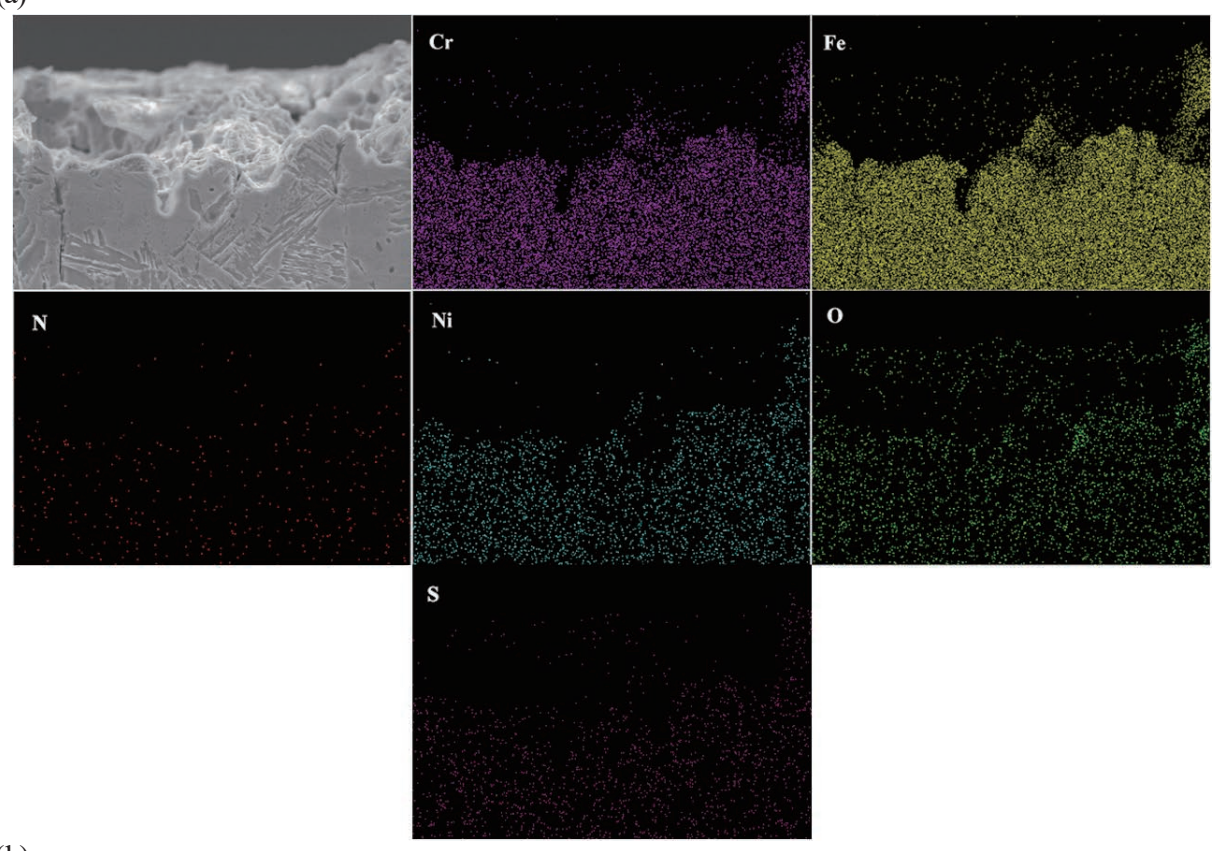

(b)

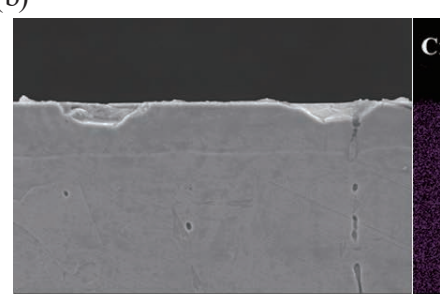

$\mathrm{Cr}$

$\mathrm{Fe}$

$\mathbf{N}$

Ni

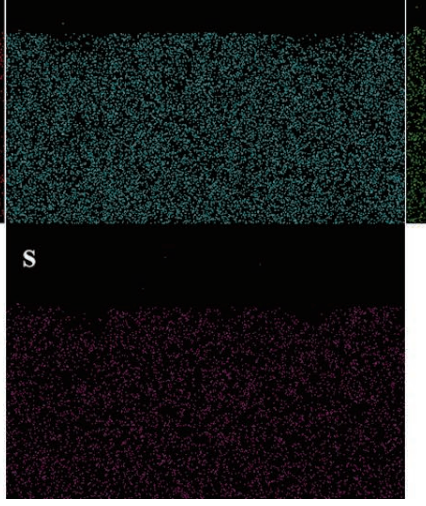

Fig. 10. EDX microanalysis of $\mathrm{Cr}, \mathrm{Fe}, \mathrm{Ni}, \mathrm{S}, \mathrm{O}, \mathrm{N}$ on corrosion products of the nitrided and unnitrided samples after stress corrosion for 30 days. (a) unnitrided, $164 \mathrm{MPa}$, (b) nitrided, $246 \mathrm{MPa}$. (Online version in color.)

to their low content, they are not very clear in the above picture. The content of $\mathrm{O}$ element in nitrided and unnitrided samples is much higher, which is due to the oxidation of the cross section after polishing. Based on the presence of S-phase, the content of the $\mathrm{N}$ element is higher in the surface of the nitrided sample under 120 pct YS, which does not exist in the unnitrided sample.

Values of hardness on the surface of the nitrided and unnitrided samples in different conditions are shown in Fig. 11. The microhardness of the surface of the nitrided samples is significantly higher than that of the matrix. The maximum hardness ( $\left.1320 \mathrm{HV}_{0.1}\right)$ measured from the surface is about 5 times the hardness of the matrix $\left(200 \mathrm{HV}_{0.1}\right)$. The significant lattice distortion and increasing dislocation density caused by the active nitrogen atoms entering the austenite lattice gap make the nitrided player with very high microhard-

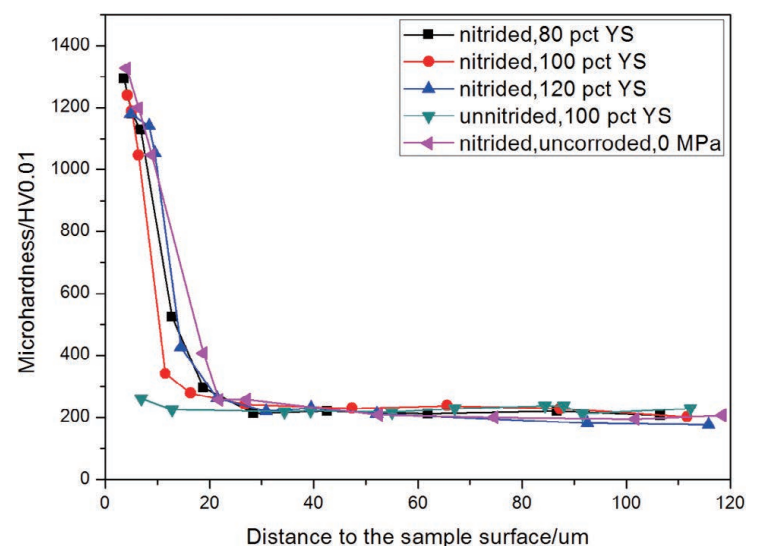

Fig. 11. The microhardness distributions of nitrided and unnitrided samples under different load stresses. (Online version in color.) 
ness. ${ }^{38)}$ However, with the increasing loading stress, the maximum surface hardness of nitrided samples reduces. Under the joint action of $\mathrm{H}_{2} \mathrm{~S}$ and loading stresses, the surface of nitrided samples may be corroded and embrittled. $\mathrm{H}^{+}, \mathrm{HS}^{-}$, and $\mathrm{S}^{2-}$ adsorbed onto the S-phase surface layer can cause hydrogen embrittlement and corrosion. ${ }^{39)}$

\section{Conclusion}

(1) Under low stresses, low-temperature liquid nitrided 321 austenitic stainless steel has better stress corrosion capability than unnitrided sample. The pitting on the surface of the nitrided sample is getting more serious with the increase of applied stress, whereas the matrix has not been damaged. The surface of the unnitrided pattern is almost all destroyed.

(2) The low-temperature liquid nitridation can reduce the formation of the corrosion products, change the local corrosion environment on the surface of the material and effectively resist hydrogen absorption which can effectively improve the corrosion resistance and SSC behavior.

(3) The tension side of the nitrided sample is more vulnerable to stress corrosion in a sour environment, compared with the compression side.

\section{Acknowledgements}

The authors are very grateful to the grant of National Natural Science Foundation of China (No. 51471112 and 51611130204), Science and Technology Planning Project of Sichuan (No. 2016GZ0173) and the Newton Mobility Grant from Royal Society, UK (IE151027) for the financial support of this research.

\section{REFERENCES}

1) R. Kane and M. Cayard: Corrosion, Proc. Corrosion 98, NACE International, Houston, TX, (1998), 22.

2) A. Turnbull and M. W. Carroll: Corros. Sci., 30 (1988), 667

3) S. Hashizume and Y. Inohara: J. Phys. Soc. Jpn., 49 (2000), 557.

4) K. G. Solheim, J. K. Solberg, J. Walmsley, F. Rosenqvist and T. H. Bjørnå: Eng. Fail. Anal., 34 (2013), 140.

5) W. T. Tsai and S. L. Chou: Corros. Sci., 20 (2000), 1741.

6) G. O. Lauvstad, R. Johnsen, O. Borck, E. F. D. Silva and J. Walmsley: Corrosion 2007, NACE International, Houston, TX, (2007), 076601.

7) G. J. Li, J. Wang, Q. Peng, C. Li, Y. Wang and B. L. Shen: J. Mater. Process. Technol., 207 (2008), 187.
8) J. W. Zhang, L. T. Lu, K. Shiozawa, W. N. Zhou and W. H. Zhang: Int. J. Fatigue, 33 (2011), 880.

9) X. Y. Li: Surf. Eng., 17 (2013), 147.

10) G. Maistro: RT Dissertation, Chalmers University of Technology, (2015), 102, https://research.chalmers.se/publication/225902, (accessed 2015-12-04).

11) X. Qin, X. Guo, J. Lu, L. Chen, J. Qin and W. Lu: J. Alloy. Compd., 698 (2016), 1094.

12) Y. Peng, C. Chen, X. Li, J. Gong, Y. Jiang and Z. Liu: Surf. Coat. Technol., 328 (2017), 420.

13) X. Y. Li and H. Dong: Mater. Sci. Technol., 19 (2003), 1427.

14) W. Li, X. Zhu, C. Wang and X. Jin: Mater. Today: Proc., 2 (2015), S691.

15) B. Larisch, U. Brusky and H. J. Spies: Surf. Coat. Technol., 116-119 (1999), 205.

16) H. Dong: Metall. Rev., 55 (2010), 65.

17) E. Haruman, Y. Sun, A. Triwiyanto, Y. H. P. Manurung and E. Y. Adesta: High Temp. Mater. Process., 30 (2011), 23.

18) H. R. Abedi, M. Salehi and M. Yazdkhasti: Mater. Lett., 64 (2010), 698.

19) B. J. Berkowitz: J. Electrochem. Soc., 129 (1982), 468

20) H. Ma, X. Cheng, G. Li, S. Chen, Z. Quan, S. Zhao and L. Niu: Corros. Sci., 42 (2000), 1669

21) E. Anelli, M. Armengol, P. Novelli and F. Tintori: High Strength Steel Pipes with Excellent Toughness at Low Temperature and Sulfide Stress Corrosion Cracking Resistance, EP 2492361 A2, (2017).

22) T. Sunaba, T. Shinohara, Y. Miyata, S. Asakura, T. Yakou and Y. Tomoe: Zairyo-to-Kankyo, 63 (2014), 468 (in Japanese).

23) H. W. Nesbitt, D. Legrand and G. M. Bancroft: Phys. Chem. Miner., 27 (2000), 357.

24) W. Sun and S. Nesic: Corrosion, Proc. Corrosion 2006, NACE International, Houston, TX, (2006), 6644.

25) C. O. A. Olsson: Corros. Sci., 37 (1995), 467.

26) Y. Fu, X. Wu, E.-H. Han, W. Ke and Z. Jiang: Electrochim. Acta, 54 (2009), 1618.

27) H. Baba, T. Kodama and Y. Katada: Corros. Sci., 44 (2002), 2393

28) R. F. A. Jargelius-Pettersson: Corros. Sci., 41 (1999), 1639.

29) X. Zhang, J. Wang, H. Fan, J. Yan, L. Duan, T. Gu, G. Xian, L. Sun and D. Wang: Metall. Mater. Trans. A, 49 (2018), 1.

30) P. R. Levey and A. R. V. Bennekom: Corrosion, 51 (1995), 911.

31) A. H. Heuer, F. Ernst, H. Kahn, A. Avishai, G. M. Michal, D. J. Pitchure and R. E. Ricker: Scr. Mater., 56 (2007), 1067.

32) Hoeft, D., B. A. Latella and K. T. Short: J. Phys. Condens. Matter, 17 (2005), 3547.

33) J. Wang, Y. Lin, M. Li, H. Fan, D. Zeng and J. Xiong: Metall. Mater. Trans. B, 44 (2013), 1010.

34) A. Galdikas, A. Petraitienè and T. Moskalioviene: Vacuum, 119 (2015), 233.

35) M. Koyama, C. C. Tasan, E. Akiyama, K. Tsuzaki and D. Raabe: Acta Mater., 70 (2014), 174.

36) K. L. Dahm, A. J. Betts and P. A. Dearnley: Surf. Eng., 26 (2010), 271.

37) Y. Sun: Surf. Coat. Technol., 228 (2013), S342.

38) S. K. Kim, J. S. Yoo, J. M. Priest and M. P. Fewell: Surf. Coat. Technol., 163 (2003), 380.

39) M. Monnot, R. P. Nogueira, V. Roche, G. Berthomé, E. Chauveau, R. Estevez and M. Mantel: Appl. Surf. Sci., 394 (2017), 132. 